\title{
Towards effective public consultation and participation in Nigeria: lessons from shoreline management plans (SMPs) activities in England
}

\author{
Taye O. Famuditi, Jonathan Potts, Malcolm Bray \\ Department of Geography, University of Portsmouth, \\ Buckingham Building, Portsmouth, United Kingdom
}

\begin{abstract}
This paper examines the shoreline management planning policy in England and its suitability for ameliorating the diverse environmental problems associated with Nigeria's coastal zones. It examines the success of SMPs in England since the mid-1990s and progress achieved, with the aim of understudying the current management approach that can be transferred to Nigeria to strengthen its adoption, and as a necessary corollary, implementation of the SMPs. This paper also examines key elements of the shoreline management frameworks in England and provides answers to the question: Would shoreline management planning approach in England be appropriate and feasible in Nigeria? It further concludes that many of the action plans and principles of participation should be adoptable provided that a participatory approach that involves all stakeholders including community members and relevant sectoral ministries as well as appropriate legal framework is encouraged.
\end{abstract}

Keywords: Shoreline Management Plans; Coastal zone management; Stakeholder engagement and Participatory approach; Nigeria

\section{INTRODUCTION}

\section{1. The Nigerian coastal zone}

The Nigerian coastline extends for about $1000 \mathrm{~km}$ along the Gulf of Guinea (Nwankwoala, 2011). Geologically, it shares boundary with Republic of Benin to the west and Cameroon toward east (Sexton \& Murday, 1994) and to the south by the Atlantic Ocean (Dublin Green et al, 1999). The coastline of Nigeria is richly endowed with immense renewable and non-renewable resources. The non-renewable resources which include crude oil and gas are the mainstay of Nigeria's economy (Osagie, Ibaba \& Watts, 2009). However, in the Niger delta part of Nigeria, the expansion of crude oil production companies combined with lack of enforcement of environmental regulations has led to significant ecological problems. This same issue is noted to be similar in most coastlines in Africa.

\section{2. Characteristics of Nigerian coast}

Characteristically, the coastal area is low lying with an average height of not more than $3.5 \mathrm{~m}$ above sea level. It is mostly covered by fresh water swamp, mangrove swamp, lagoonal mashes, tidal channels, beach ridges and sand bars (Dublin- Green et al, 1997). 
Previous studies on the geomorphology of the Nigerian coastline conducted by Pugh (1954), NEDECO (1954); Allen (1965) and Ibe and Anita (1983) classified it into four distinct geomorphological units: (Figure 1) the Barrier-Lagoon complex, the Transgressive Mud beach or Mahin Mud coast, the Niger Delta and the Strand Coast. These different sections of the Nigerian coastline could be described based on associated natural and anthropogenic factors.

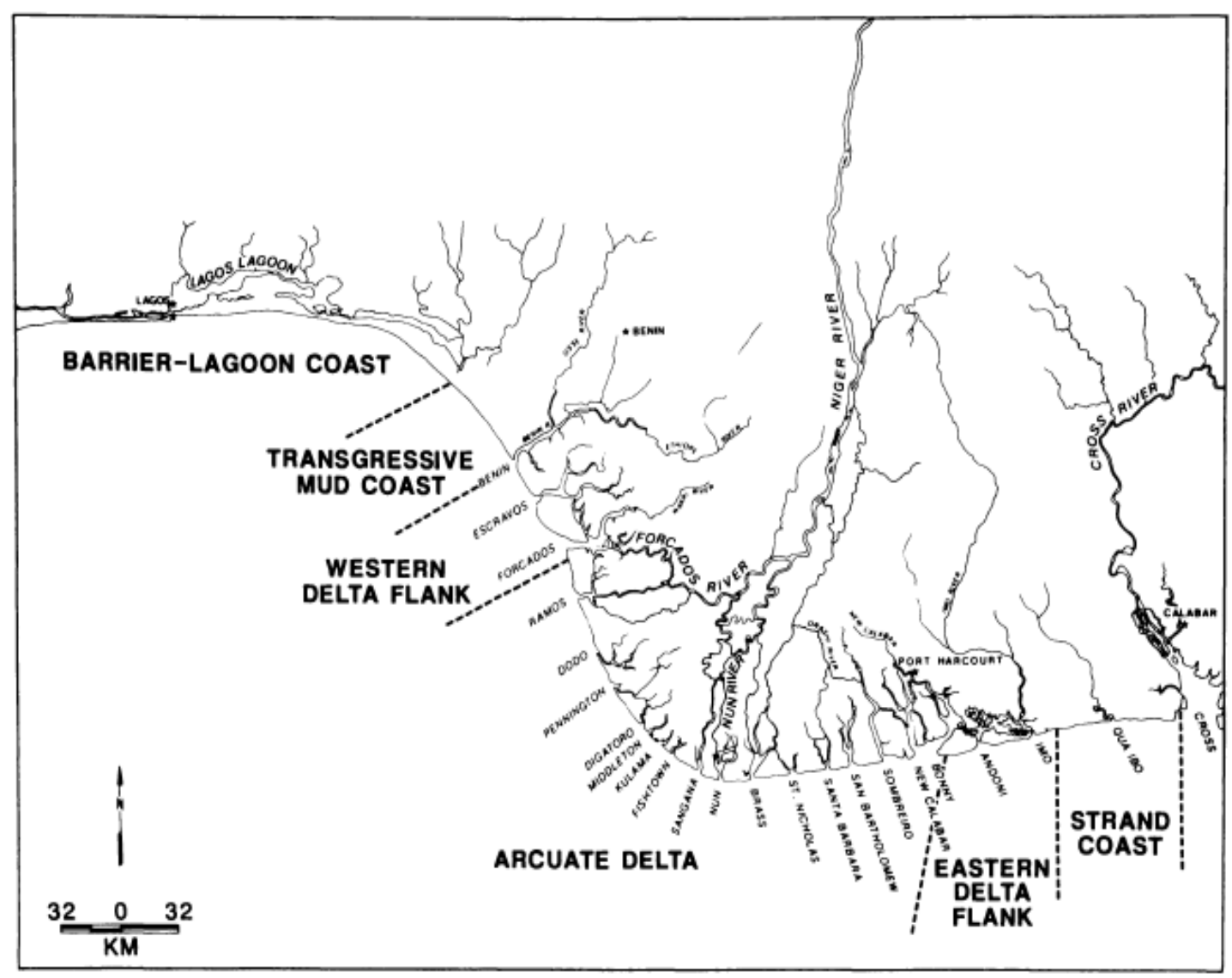

Figure 1. Map of the Nigerian Coastal Areas (Sexton \& Murday, 1994).

\section{KEY ISSUES FACING COASTAL AREA IN NIGERIA}

During the past decades coastal area development in Nigeria has witnessed a rapid growth through the expansion of urbanization, industrialization, tourism and other land-based activities. It is estimated that no fewer than $60 \%$ of the country population within $30 \mathrm{~km}$ of the coastal zone region (Sokari, 1989). This growth has led to increasing pressures on the coastal and the adjacent marine environment. The Nigerian coastal environment is being challenged and threatened by environmental problems which are caused by human as well as natural factors. Amongst the common environmental problems are population pressure, coastal erosion and flooding, oil spills, dredging, ports construction and over and over fishing. It is estimated that $80 \%$ of Nigerian lands are affected by coastal erosion (Akegbejo, 2013). Tackling such ecological and socio economic impacts requires a holistic, integrated and participatory approach. 
With the impacts of sea level and other potential climate changes, the exposure of large parts of Nigerian coastline to significant coastal flooding and erosion will worsen. Without effective legal and institutional framework for management, the consequence could be considerable threatening livelihoods and putting properties, agricultural land, business and other assets at risk.

\section{1. Oil incidents along the Nigerian coast}

Commercial oil production began in Nigeria in 1958 after discovery by Shell British Petroleum (now Royal Dutch Shell) (Egberongbe, et al. 2006). Currently Nigeria has been ranked as one of the world's largest oil exporter. Petroleum industries located in the Niger Delta region of Nigeria has added to regular oil incident along these coastlines. Oil spillage as a result of sabotage, corrosion of pipes and storage tanks, and carelessness during oil production operations (Nwilo and Badejo, 2006) are one of the major environmental threats facing Nigeria. Spills often spread out over a wide populated coastal area, destroying large areas of the mangrove ecosystem through groundwater contamination. In many cases, it has caused significant conflict between coastal inhabitants and multinational oil companies operating in the region (Omeje, 2005).

\section{COASTLINE MANAGEMENT IN NIGERIA}

There is no specific policy legislation for management of coastal area, neither a specific definition of coastal area. Neither is there a specific definition of the coastal zone in the Nigeria national legislation. (Sokari, 1989). However there were several policies aimed at managing shoreline which were unsuccessful due to the absence of effective monitoring. Considering efforts in tackling coastal flooding problems, the Federal Government created the Department of Erosion, Flood and Coastal Zone Management, an arm of the Federal Ministry of Environment with primary responsibility to develop strategies for the prevention and control of inland and coastal erosion, flood and coastal land degradation.

Alongside a divided political system is a divide within government ministries. There is no active coordination between the organisation at the Federal and the State level. Coastal zone management came under the remit of the Federal Ministry of Environment, while the Federal Environmental Protection Agency (FEPA) was also given similar responsibility of development policies to manage the coastline. The system has therefore been characterised by fragmentation, duplication of tasks, overlapping responsibilities and the existence of political and administrative boundaries and subsequent inconsistencies, which has created a confusion preventing coordination and effective management of the coast.

In a bid to manage oil spill incidents several laws and policies has been formulated to provide the regulatory framework for oil operations that could have environmental impact on the host communities. It also made provisions to facilitate the promotion and implementation of policy, as well as encourages information exchange. However, some of the acts and regulations on pollution are suggested to be enforced. Due to increasing awareness in participatory approach to preventing and controlling oil spill conflicts in Nigeria.

The Federal Government passed into law the establishment of Niger Delta Development Commission (NDDC) in 2000. The primary purpose of establishing the NDDC was to offer a lasting solution to the socio-economic, ecological/environmental remediation of the Niger delta region through involvement of stakeholders at all levels (individual, group 
and community) to participate fully in the planning and decision making process (Anietie, 2006). Recently, in 2013, the organisation has come under scrutiny and concerned Niger Delta residents have regarded it as rather than being a vehicle for the rapid development of the Niger Delta, it has become a vehicle of corruption and embezzlement by some politicians. It is clear from discussions so far in this section that past institutional frameworks did not provide for an integrated approach to shoreline management in Nigeria. The failings of this management system need to be improved in order to promote a partnership approach to management.

\section{SHORELINE MANAGEMENT PLANS: DEFINITION}

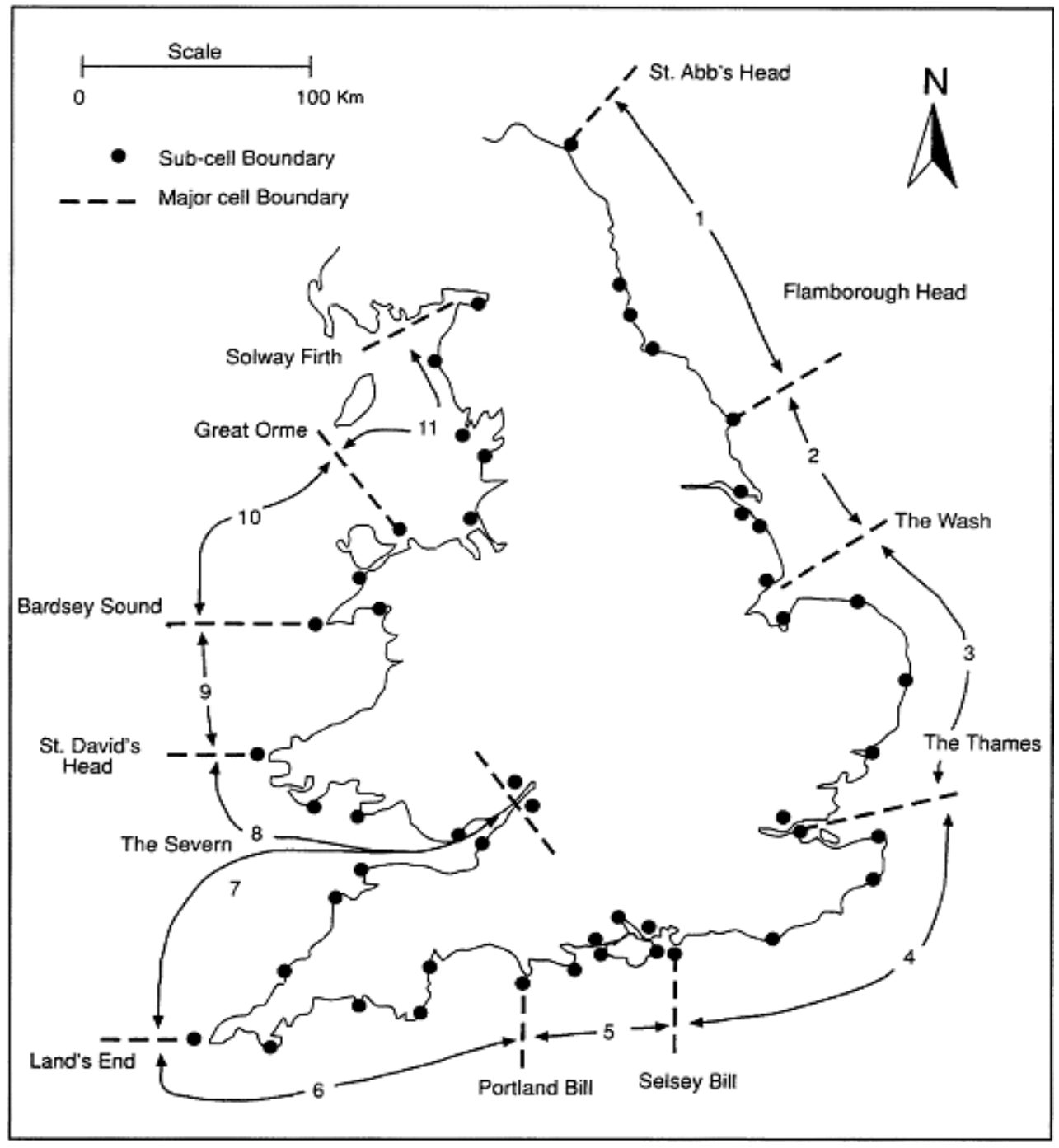

Figure 2. Sediment cells established for England and Wales. Cooper \& Pontee (2006).

The Ministry of Agriculture, Fisheries and Food (MAFF), which later became the Department for the Environment, Food and Rural Affairs (Defra); and the Welsh Office (WO), which later became the Welsh Assembly Government (WAG) jointly published a flood and coastal defence strategy for England and Wales in 1993, coastal managers and decision 
makers were encouraged to work together in coastal groups to develop Shoreline Management Plans (SMPs). These non-statutory plans are considered to be a key part of sustainable coastal risk management, identifying future policy that is technically and environmentally sustainable and economically viable.

A SMP can be considered a long-term strategic approach to the management of risks such as coastal erosion, flooding and land instability in England and Wales (Atkinson \& Fisher, 2004; Ballinger, Taussik \& Potts, 2004). It also provide the policy framework from which more detailed strategies and schemes are developed to help manage these risks to people and to the developed, historic and natural environment in a sustainable manner over the next 100 years (Defra 2006 a, b, \& c). The coastal boundaries of SMPs are based upon sediment cells (Figure 2). The cells were defined by the sediment transport process in each unit (Hooke \& Bray, 1995, Cooper \& Pontee, 2006).

The Shoreline Management Plan is a non-statutory, high level policy document for coastal flood and erosion risk management planning (Defra, 2006). It takes account of other existing planning initiatives and legislative requirements, and is intended to inform wider strategic plans that the Environment Agency and Local Authorities use to plan their work to manage coastal risks (Defra, 2001; Hutchison, 2008), as explained in Table 1.

Table 1. Stages in assessing the risk of floods and erosion (Defra, 2006a; Pontee, \& Parsons, 2010).

\begin{tabular}{|c|c|c|}
\hline Policy option & Description & Non-technical description \\
\hline Hold the line & $\begin{array}{c}\text { by maintaining or changing the standard of } \\
\text { protection. This policy includes those situations } \\
\text { where work is carried out in front of the existing } \\
\text { defences to improve or maintain the standard of } \\
\text { protection provided by the existing defence line. }\end{array}$ & $\begin{array}{c}\text { Keeping the shoreline in the } \\
\text { same place }\end{array}$ \\
\hline Advance the line & $\begin{array}{c}\text { by building new defences on the seaward side of } \\
\text { the original defences. }\end{array}$ & $\begin{array}{c}\text { Creating more land by moving } \\
\text { coastal defences into the sea }\end{array}$ \\
\hline $\begin{array}{c}\text { Managed } \\
\text { realignment }\end{array}$ & $\begin{array}{c}\text { by allowing the shoreline to move backwards or } \\
\text { forwards, in a managed way to control or limit } \\
\text { risk }\end{array}$ & $\begin{array}{c}\text { Letting the shoreline move } \\
\text { forward or backwards in a } \\
\text { controlled way }\end{array}$ \\
\hline $\begin{array}{c}\text { No active } \\
\text { intervention }\end{array}$ & $\begin{array}{c}\text { where there is no justification to intervene with } \\
\text { coastal defences or operations. }\end{array}$ & $\begin{array}{c}\text { Letting nature take its course on } \\
\text { the shoreline }\end{array}$ \\
\hline
\end{tabular}




\section{1. Objectives of SMP}

The main aim of a SMP is to indicate how best to reduce risks to people and the developed, historic and natural environment in a variety of ways through (O'Riordan and Ward, 1997; MAFF, 2000, Defra, 2006):

- The provision of adequate and cost effective flood warning systems;

- The provision of adequate flood and coastal defence measures that are technically, environmentally and economically sound and sustainable;

- Discouraging inappropriate development in areas at risk from flooding or coastal erosion.

- Identifying all human-made and natural features likely to be affected by coastal change

- Facilitating consultation amongst those bodies with an interest in a shoreline.

\section{RISK MANAGEMENT: SHORELINE MANAGEMENT FRAMEWORK}

The overall plan and associated policies presented in SMPs are the result of numerous studies and assessments performed over a period of time to support decision-making about the extent to which a specific stretch of coast should be defended or more natural processes be allowed to continue. Four generic Strategic Coastal Defence Options, (SCDO) were being identified by MAFF and these are considered for each management unit as outlined in its main objectives (Defra, 2006). Each SCDO was initially reviewed on the basis of its compatibility with natural processes, the implications on human environment, natural environmental acceptability, technical soundness and sustainability, economic viability and its wider impacts. Table 2 explained the shoreline management policies that are considered and its non-technical explanations (Cooper et al, 2001, Defra, 2001; Defra, 2006).

Table 2. Explained the shoreline management policies that are considered and its non-technical explanations (Cooper et al, 2001, Defra, 2001; Defra, 2006).

\begin{tabular}{|c|c|c|c|}
\hline Stage & SMP & Strategy & Schemes \\
\hline Aim & $\begin{array}{l}\text { To identify policies to } \\
\text { manage risks }\end{array}$ & $\begin{array}{l}\text { To identify appropriate } \\
\text { schemes to put the policies } \\
\text { into practice }\end{array}$ & $\begin{array}{l}\text { To identify the type of work } \\
\text { that is needed to put the } \\
\text { preferred scheme into } \\
\text { practice }\end{array}$ \\
\hline Delivers & $\begin{array}{c}\text { A wide-ranging } \\
\text { assessment of risks, } \\
\text { opportunities, limits and } \\
\text { areas of uncertainty } \\
\end{array}$ & $\begin{array}{l}\text { Preferred approach, including } \\
\text { economic and environmental } \\
\text { decisions }\end{array}$ & $\begin{array}{l}\text { Compares the different } \\
\text { options for putting the } \\
\text { preferred scheme into } \\
\text { practice }\end{array}$ \\
\hline Output & $\begin{array}{l}\text { Policies (eg. Hold the } \\
\text { line, retreat, managed } \\
\text { realignment }\end{array}$ & $\begin{array}{l}\text { Type of scheme (such as a } \\
\text { seawall, beach recharge) }\end{array}$ & $\begin{array}{l}\text { Design of work (such as } \\
\text { revetment walls) }\end{array}$ \\
\hline Outcome & $\begin{array}{l}\text { Improved long-term, } \\
\text { strategic management for } \\
\text { the coast }\end{array}$ & $\begin{array}{l}\text { Management measures that } \\
\text { will provide the best approach } \\
\text { to managing floods and the } \\
\text { coast for a specified area }\end{array}$ & $\begin{array}{l}\text { Reduced risks from floods } \\
\text { and coastal erosion to people } \\
\text { and assets }\end{array}$ \\
\hline
\end{tabular}




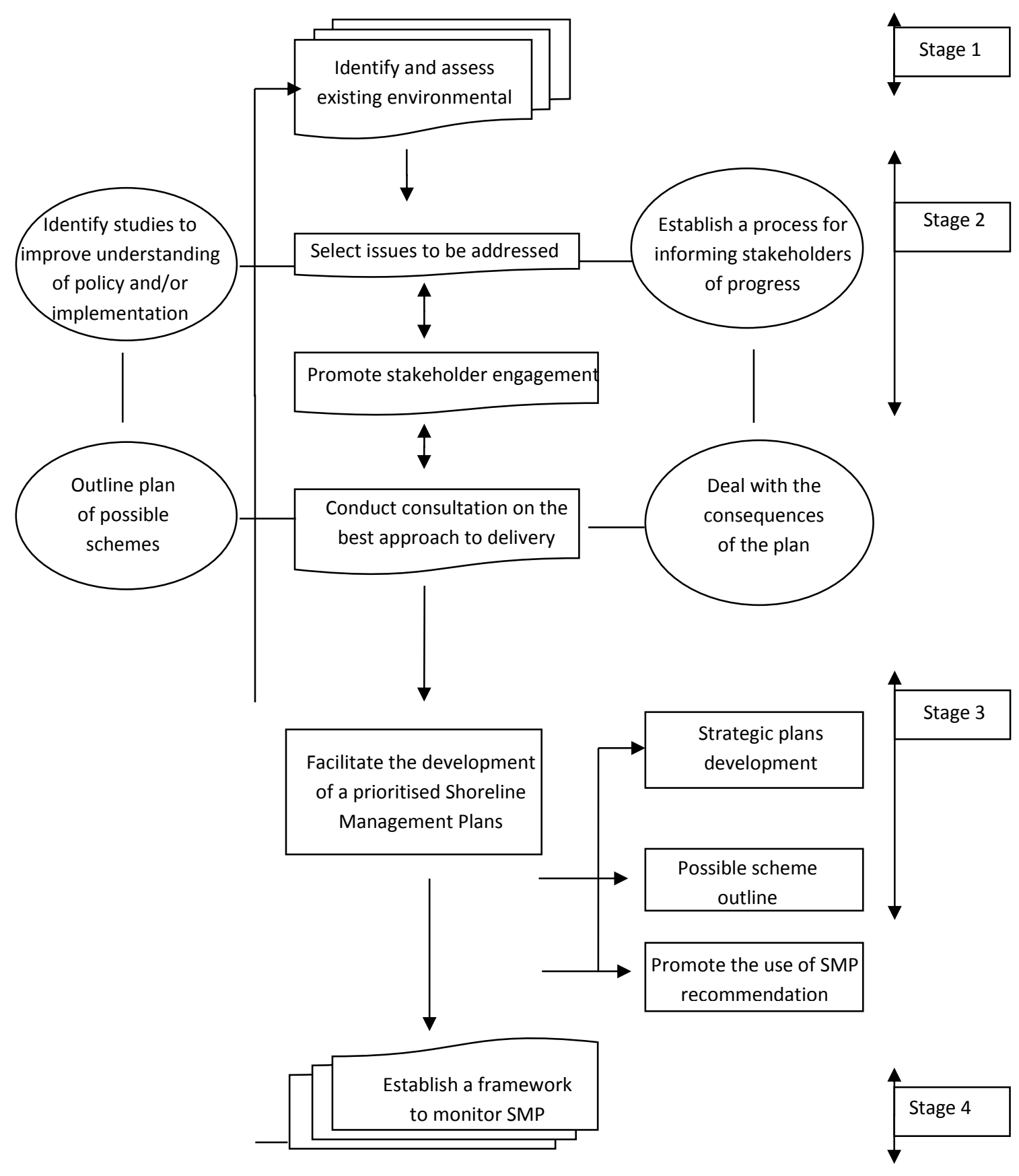

Figure 3. Shoreline management plans policy options (Edited form: Defra 2001).

\section{BENEFITS OF PARTICIPATION IN COASTAL MANAGEMENT}

Community engagement in the management of coastal areas has become an increasingly significant element of sustainable development (Dahl, 1997). International prescriptions support the need for stakeholder participation in the delivery of sustainability aspirations. For example, following the Earth Summit in Rio de Janeiro in June 1992 within Agenda 21, it is 
asserted, "one of the fundamental prerequisites for the achievement of sustainable development is broad public participation in decision-making'" (UNCED, 1992, para 23.2) The criteria given for successful participation in coastal zone management by Cicin-Sain and Knecht (1998) assume that, once within a decision-making process, participants are equally empowered and that the decision-making process is fair to all involved. In effect it is assumed that any decision-making process is fair and competent. As identified by Treby and Clark (2004) and Van den Hove (2006), successful participation should have consensus as a goal, where the results are legitimate and accepted by all stakeholders, and produce both "outputs" (tangible products) as well as "outcomes" at the meaningful end of continua

Specifically, in England, participation has been central to the development of SMP2 (Environment Agency, 2009). Effective external stakeholder and public engagement has been essential for identification of key issues, definition of SMP objectives, and the selection of the preferred SMP policy.

The most noticeable differences between consultation in the first and second round SMPs are listed below (Pontee \& Parsons, 2010):

- extensive involvement of stakeholders throughout the policy development process to improve auditability.

- stakeholders are given an opportunity to comment on the environmental appraisal of options;

- SMP2 allowed representations made by the stakeholders to be taken into account in the selection of policy options; and

- public are given opportunity to comment on the preferred policies.

Ultimately, inclusion of stakeholders or those affected by a particular decision in the decision-making process is likely to result in supporting the implementation of that decision (Stojanovic et al., 2004). In addition, when people attribute the consequences of their actions to their personal efforts, they assume responsibility for their situation. In doing this, they feel the importance of their physical and social surroundings (Horelli, 2002).

\section{LESSONS TO BE LEARNT FROM THE ENGLAND MANAGEMENT PLANNING}

Coastal risk management involves recognising the most effective and appropriate ways risks to people and natural environment can be managed and how to put these into practice (Defra, 2006a). Nigerian coasts, in comparison to the coastline in England, are in good natural state, the rapid development of the last few decades has brought an alarming evidence of environmental degradation.

There are many differences in public participation in shoreline management between Nigeria and England. Firstly, there are no specific environmental management regulations concerning public participation in Nigeria. Also in the Nigerian Environmental Impact Assesment Decree No. 86 of 1992 (document with aim of protecting the Nigerian environment), the scope of the public is defined vaguely; there is no definition of 'public' or who should be involved in planning and management (EIA, 1995).

In England, however, there is a a clear definition of the public in SMPs; these plans include local directly affected people, indirectly affected people, developers, and experts in shoreline management practice. SMP2 made provision for the public to participate in decision making processes. In the guidelines for managing shoreline in England, public 
participation has been included from the stage of scoping to the implementation period; each stage has a specific goal and participation methods. Theoretically speaking, it is essential to develop the same approaches to public involvement in Nigeria, primarily because any change in the existing level of coastal resource management in favour of new policy is likely to cause much local upset if SMPs or similar plans were to be adopted.

As currently observed in Nigeria, conflicting issues in the coastal zone are managed by the government through different administrations at various levels, all having their own political or strategic agenda, thus complicating the sustainable management of the coastal zone. It is essential to incorporate in the process the opinions of all the involved and interested parties. Through adoption of SMPs or element of SMPs Nigeria could potentially learn the strategies of involvement of public and stakeholders in policy making and implementation in order to reduce conflicts between coastal management authorities, developers, governments and other involved parties, and thus ultimately to a more effective process. In sustainable management of the coastal zone, integration mechanisms are only one element. Tactical action is needed also in the management of oil pollution control, land use planning and environmental impact assessment. As noticed in Nigeria, the diversity of administrative regulations and approaches to planning and management of the coastal areas, inadequate and irregular funding as well as little or no understanding of coastal environment behaviours have been critical obstacles towards developing a management approach to coastline, until recently, this is similar issue in development of SMP in England.

\section{RECOMMENDATIONS}

The recommended actions associated with different stages in developing a sustainable management plan for coastal management, outlined in Figure 3, have been formulated to meet the aim of this paper which was to present element of the shoreline management approach to Nigeria for its adoption, as discussed in the following paragraphs.

\section{1. Stage 1: Issue identification and assessment}

The first stage in the evaluation process of managing the shoreline is to identifying issues and providing the appropriate ways to manage its risk to people and natural environment, this is very essential. It is recommended to identify studies to improve understanding of the coastal environment and recognize any possible conflicts. There is need for comprehensive assessment of the status of Nigerian coastline (Eni et al, 2011). The use of information, knowledge and technology are amongst essential aspects of achieving better integrated results in the sustainable management of coastal areas. For example, the Futurecoast document created in 2002 by the Defra has proven to be a useful tool for coastal managers as it provides all the needed information to tackle shoreline management issues in the short and long-term as well as providing information to improve understanding of coastal systems and their behavioural characteristics (Burgess \& Hosking, 2004).

Currently, in Nigeria, sharing information and knowledge through various media is increasing. This idea can be adopted between coastal managers and stakeholders. A good relationship between management authorities and experts (consultants) strengthens the exchange of knowledge and information thereby providing a better basis for sustainable management of coastal areas. "By promoting networking and other forms of interactive communication and by incorporating the ideas and suggestions of the affected parties into 
management objectives, behavioural solutions produce a movement away from individual self-interested choices" (Chance and Draper, 1996, p. 181).

\section{2. Stage 2: Programme preparation: stakeholder engagement}

The second stage in this process is to engage stakeholders. In many cases, coastal management authorities often need to make difficult decisions regarding the protection, restoration and development of their coastal areas. The majority of these decisions frequently lead to protest and therefore causing delay in the decision-making process. To find a balance between sustainable management and the often conflicting individuals could be highly demanding and time-consuming. However, by engaging the stakeholders in the selection and analysis of management plans will yield a good outcome. An example from Medmerry in the England shows how local community participation in Managed Realignment scheme has provided a new way of thinking, in the influencing of the coastal strategies and plans, and in improving protection against flooding and creating new environments for nature and human activities. As experienced in England, the most vital consideration may be about local community participation and what they can offer, rather than imposing decision of management of coastline. Through this approach, the hope is that public participation will not only contribute to overcoming the conflicts along the coastline through better governance but also meet developmental plans of improved communities' engagement in decision making.

\section{3. Stage 3: Coastal zone management implementation}

The third step involves creating public awareness and fostering public participation. This is a key element to implementation of sustainable practice. Protection and development of an area in a sustainable way can be successful if all those who live in the area are committed participated in the management plans, as illustrated in an example from Medmerry in England, where, for the first time, a wide range of stakeholders and local residents were brought together at the start of a new proposed management scheme. The partners came from local, regional and national level, public and private sectors, as well as government representatives to agreed and adopt suitable policy option which will allow sustainable management along with the preservation of their valuable coastal natural environment.

From the point of view of the oil pollution issue outlined earlier in this paper, it is important that the measures should be put in place to control the operation of petroleum in the coastal cities of Nigeria. Also monitoring must be increased so that oil operation can be kept in check from pollution and offenders can be prosecuted under relevant act.

\section{4. Stage 4: Evaluation and monitoring}

This ultimate stage, in many cases will involve a combination of measures including, for example, involvement of different stakeholders and local communities, working with planning authorities to achieve the same objectives. Management of the coastal zone is a learning process with incremental monitoring, feedback and adjustment mechanisms. It is recommended that issues and strategies should be constantly reassess and every action keep focus on issues which are understood by all the participants in the process. In addition, at all levels of stage, it is important that the decision-making system is just and efficient. Due to poverty level in some rural communities in Nigeria, it is very essential to understand that effective participatory approach with the residents could be complicated. Because of this, prompt action is needed on urgent needs and priorities of the local community as it arises. 


\section{CONCLUSIONS}

Many valuable lessons can be drawn from the process of consultations and participations in shoreline management experience in England. Those lessons can hopefully help Nigeria to make strategic policy decisions before embarking on coastal management of any kind as well developing as legal frameworks for strengthening public engagement. This article has identified the need for participatory approach in management of Nigeria coastline. Furthermore, overlapping statutory and inadequacies in environmental management are traceable to lapses in Government responsibilities. The lessons of the shoreline management planning in England can be used by Nigeria as inputs for considering strategies and approaches to coastal zone management. The entire range of lessons, together with knowledge on existing management planning systems in England, need to be analysed and considered before any coastal zone management is undertaken in Nigeria.

There will continue to be conflicts along the coastline as a result of increase population and multiple users. Developing consultation within the local residents may be more important part of conflict resolution along the coastline. However Nigeria, by building on its own strengths of local knowledge, biodiversity and community requirements can resolve conflict which arises as a result of multiple use of the coastline through appropriate consultation and participatory governance. In conclusion, it is suggested the Nigeria can adopt the shoreline management planning in England, since it provides a good example in participatory management system.

\section{References}

[1] Akegbejo-Samsons Y. (2013). Development Challenges of Multi-Functional Coastal System in the Niger Delta, Nigeria. In Climate Change and Disaster Risk Management (pp. 107-116). Springer Berlin Heidelberg.

[2] Allen J., Geologie en Mijnbouw. 44 (1965) 1-21.

[3] Anietie Usen (2006). Making a difference in the Niger Delta: February 2001 September 2006. Port Harcourt, Nigeria: NDDC Corporate Affairs Department.

[4] Atkinson A., Fisher E. (2004). Shoreline management plans: first review. In D. Green (Ed.), Littoral 2004, 7th International Symposium: Delivering sustainable coasts: Connecting science and policy (pp.199-204). Aberdeen, Scotland: Cambridge Publications.

[5] Ballinger R., Taussik J., Potts J. (2004). Sharing responsibility for managing coastal risk: lessons from the British experience. In D. Green (Ed.), Littoral 2004, 7th International Symposium: Delivering sustainable coasts: Connecting science and policy (pp.199- 204). Aberdeen, Scotland: Cambridge Publications.

[6] Burgess K., Jay H., Hosking A., Journal of Coastal Conservation 10(1) (2004) 65-71.

[7] Chance C., Draper D., Environmental Management 20(2) (1996) 175-184.

[8] Cicin-Sain B., and Knecht R.W (1998). Integrated coastal and ocean management: Concepts and practice. Washington DC: Island Press.

[9] Cooper N., Pontee N., Ocean and Coastal Management 49(7-8) (2006) 498-510. 
[10] Cooper N. J., Barber P. C., Bray M. J., Carter D. J., Proc of the Institution of Civil Engineers (Water and Maritime Engineering) 154(3) (2001) 221-228.

[11] Dahl C., Ocean and Coastal Management 36(1-3) (1997) 23-45.

[12] Department for Environment, Food and Rural Affairs. (2001). Shoreline management plans: A guide for coastal defence authorities. London: Defra.

[13] Department for Environment, Food and Rural Affairs. (2006). Shoreline management plan guidance, volume 1: aims and requirements. London: Defra.

[14] Dublin-Green C. O., L. F. Awosika, R. Folorunsho (1999). Climate Variability Research Activities In Nigeria. Nigerian Institute for Oceanography and Marine Research, Victoria Island, Lagos, Nigeria.

[15] Egberongbe, F. O. A., Nwilo, P. C., \& Badejo, O. T. (2006). Oil spill disaster monitoring along Nigerian Coastline [Electronic Version]. Available online at http://www.fig.net/pub/fig2006/papers/ts16/ts16_02_egberongbe_etal_0223.pdf.

Accessed on 4 September 2007.

[16] Eni D. I., Oka P. O., Atu J. E., Sacha Journal of Environmental Studies 1(2) (2011) 1-7.

[17] Environment Agency. (2009). Folkestone to Cliff End flood \& erosion management strategy consultation summary report. Retrieved 11 November, 2012 from http://www.environment-

agency.gov.uk/static/documents/Leisure/FoCES_Consultation_Summary_Report.pdf.

[18] Environmental Impact Assessment (1995). Procedural Guidelines: The Federal Ministry Of Environment, Lagos, Nigeria

[19] Hooke J., Bray M., Area 27(4) (1995) 358-368.

[20] Horelli L. (2002). A methodology of participatory planning. In: Handbook of Environmental Psychology (ed. R B Bechtel and A Churchman), pp. 629-646. New York: John Wiley \& Sons.

[21] Hutchison, J. (2008). The management of our shoreline: how can we make it work using resources and funding to best effect. In Flood and Coastal Risk Management Conference 2008: Conference Handbook, 1-3 July 2008.

[22] Ibe A. C., Antia E. E. (1983). A preliminary assessment of the impact of erosion along the Nigerian shoreline, NIOMR Tech. Paper No. 13, p. 19.

[23] MAFF. (2000). A review of shoreline management plans 1996-1999. London: MAFF

[24] NEDECO. (1954). Western Niger Delta. the Hague: NEDECO. Pugh, J. C. (1953) Port Novo - Badagry Sand Ridge Complex. Research Notes, Department of Geography, University College, Ibadan, No. 3.

[25] Nwankwoala H., Journal of Applied Technology in Environmental Sanitation 1(4) (2011) 371-380.

[26] Nwilo P. C., Badejo O. T., Administering Marine Spaces: International Issues 119 (2006).

[27] O’Riordan T., Ward R., Land Use Policy 14(4) (1997) 257-276.

[28] Omeje K., New Political Economy 10(3) (2005) 321-334. 
[29] Osagie S. O., Ibaba S. I., Watts M., Journal of African Development 11(2) (2009) 9-26.

[30] Pontee N. I., Parsons A., Proceedings of the ICE-Maritime Engineering 163(1) (2010) $31-42$.

[31] Pugh J. C., Journal of West African Science Association, (1954) 1-12.

[32] Sexton W. J., Murday M., Journal of coastal research (1994) 959-977.

[33] Sokari-George E., GeoJournal 18(3) (1989) 285-289.

[34] Stojanovic T., Ballinger R. C., Lalwani C. S., Ocean \& Coastal Management 47(5) (2004) 273-298.

[35] Treby E. J., Clark M. J., Coastal Management 32 (2004) 353-372.

[36] UNCED (1992). Rio Declaration on Environment and Development, The United Nations Conference on Environment and Development, Rio de Janeiro 3-14 June 1992.

[37] Van den Hove S., Land Use Policy 23 (2006) 10-17. 